Jurnal Vijjacariya, Volume 6 Nomor 2, Tahun 2019

\title{
KEPUASAN MAHASISWA PROGRAM STUDI PENDIDIKAN AGAMA BUDDHA TERHADAP PELAYANAN TEKNOLOGI DAN SISTEM INFORMASI PERGURUAN TINGGI KEAGAMAAN BUDDHA DI TANGERANG
}

\author{
Oleh \\ Heriyanto, Hendrian Yonata \\ STABN Sriwijaya, STAB Dharma Widya \\ heriyanto@stabn-sriwijaya.ac.id, hendrianyonatadecoco@gmail.com
}

\begin{abstract}
ABSTRAK
Permasalahan penelitian ini adalah bagaimanakah kepuasan mahasiswa program studi Pendidikan Agama Buddha (Prodi PAB) terhadap pelayanan teknologi dan sistem informasi Perguruan Tinggi Keagamaan Buddha (PTKB) di Tangerang. Penelitian ini bertujuan mendeskripsikan kepuasan mahasiswa Prodi PAB terhadap pelayanan teknologi dan sistem informasi PTKB di Tangerang. Penelitian juga bertujuan untuk mendeskripsikan tingkat kepuasan mahasiswa Prodi PAB terhadap pelayanan teknologi dan sistem informasi ke dalam kategori tinggi, sedang, dan rendah. Penelitian ini merupakan penelitian deskriptif dengan pendekatan kuantitatif. Subjek penelitian adalah mahasiswa Prodi PAB pada PTKB di Tangerang yang berjumlah 86 orang. Objek penelitian adalah kepuasan mahasiswa Prodi PAB terhadap pelayanan teknologi dan sistem informasi. Penelitian ini merupakan penelitian populasi yang dilakukan dengan teknik nontes menggunakan kuesioner. Lokasi penelitian yaitu pada Sekolah Tinggi Agama Buddha Negeri Sriwijaya Tangerang Banten (STABN Sriwijaya) dan Sekolah Tinggi Agama Buddha (STAB) Dharma Widya. Kuesioner menggunakan empat klasifikasi berdasarkan skala Likert. Teknik analisis data dengan teknik statistik deskriptif menggunakan nilai rata-rata (mean) dan standar deviasi. Hasil penelitian menyatakan kepuasan mahasiswa Prodi PAB terhadap pelayanan teknologi dan sistem informasi PTKB di Tangerang sebesar 77,28\%. Interpretasi yang didapat dengan mencari interval skor persen berdasarkan skala Likert menyatakan $77,28 \%$ termasuk dalam kategori sangat puas. Tingkat kepuasan mahasiswa sebesar 14,00\% dalam kategori tinggi, 79,00\% kategori sedang, dan 7,00\% dalam kategori rendah. Tingkat kepuasan mahasiswa Prodi PAB terhadap pelayanan teknologi dan sistem informasi PTKB di Tangerang untuk dimensi tangible sebesar 79,51\%, dimensi reliability sebesar 76,82\%, dimensi responsiveness sebesar 77,17\%, dimensi assurance $77,42 \%$, dan untuk dimensi emphaty sebesar $75,56 \%$.
\end{abstract}

Kata kunci: Kepuasan Mahasiswa, PTKB

\section{PENDAHULUAN}

Sarana dan prasarana pendidikan menjadi alat dalam menciptakan efektivitas proses, meningkatkan pelayanan, dan mencapai tujuan pendidikan. 
Teknologi dan sistem informasi dalam bentuk sarana dan prasarana menjadi alat untuk semakin terdepan, meningkatkan daya kompetitif, dan menjadi kunci keberhasilan dalam menjalankan proses operasional akademik pada perguruan tinggi. Layanan sistem informasi menjadi wujud baru pelayanan administrasi akademik perguruan tinggi yang syarat akan berbagai fungsi dan pemanfaatan teknologi serta sistem informasi.

Pemanfaatan berbagai peralatan teknologi seperti komputer, sistem informasi akademik, website kampus, sistem informasi perpustakaan, fasilitas akses internet, serta berbagai aplikasi yang digunakan dalam mendukung proses akademik mahasiswa merupakan bentuk layanan teknologi dan sistem informasi pada perguruan tinggi. Hasil yang diharapkan secara langsung adalah kepuasan mahasiswa terhadap pelayanan perguruan tinggi yang berimbas pada mutu proses pendidikan yang dilakukan. Evaluasi terhadap implementasi mutu di lingkungan perguruan tinggi salah satunya adalah dengan melihat berjalannya sistem yang sesuai dengan standar yang sudah ditetapkan, standar sarana dan prasarana dengan indikator teknologi dan sistem informasi yang juga merupakan bagian di dalamnya. Kaitannya dengan pemanfaatan teknologi dan sistem informasi perguruan tinggi dalam memberikan layanan terhadap mahasiswa, penggunaan teknologi dan sistem informasi tersebut harus mencapai efektivitas yang baik dengan menghasilkan tingkat kepuasan mahasiswa yang tinggi terhadap layanan yang diberikan.

Kepuasan mahasiswa merupakan cerminan pelayanan yang bermutu, juga dalam hal fasilitas teknologi dan sistem informasi perguruan tinggi. Perkembangan masyarakat membawa pada keadaan di mana perguruan tinggi harus beradaptasi untuk meningkatkan kualitas yang berorientasi pada customer value. Pada perguruan tinggi, kinerja program studi dengan berbagai sumber daya yang ada harus berada pada taraf yang maksimal untuk memberikan pelayanan terhadap mahasiswa, ketercapaian tujuan pendidikan yang dilakukan, serta memberikan kepuasan terhadap mahasiswa sebagai penerima jasa pendidikan. Kenyataan yang ada, urgensi kepuasan mahasiswa tidak selalu terjawab dengan maksimal, banyak mahasiswa yang tidak puas terhadap pelayanan akademik yang diberikan, khususnya dalam pelayanan administrasi. Banyaknya perguruan tinggi yang kurang mengakomodir kebutuhan mahasiswa dalam menyediakan fasilitas teknologi dan sistem informaasi. Bandwith internet yang rendah, pemanfaatan sistem informasi akademik tidak maksimal, dan juga respon serta keramahan tenaga kependidikan terhadap mahasiswa yang dirasa masih kurang. Pelayanan teknologi dan sistem informasi tidak hanya seputar fasilitas maupun sarana dan prasarana, tetapi juga meliputi respon dalam bentuk layanan yang diberikan, baik dari tingkat jurusan, program studi, dan setiap individu tenaga kependidikan.

Di era modern seperti sekarang ini, dengan ciri masyarakat yang semakin digital dan keterbukaan informasi, pelayanan administrasi yang maksimal dengan pemanfaatan teknologi dan sistem informasi yang menjadi 
sebuah keharusan, yang akan mengakomodir berbagai kebutuhan mahasiswa. Pemanfaatan teknologi dan sistem informasi dalam dalam berbagai proses akademik menjadi komponen utama untuk menciptakan kepuasan mahasiswa. Lebih lanjut kepuasan mahasiswa akan membentuk daya kompetitif tinggi bagi perguruan tinggi, tercapainya visi dan misi, serta peningkatan mutu pendidikan yang dilakukan.

Pada lingkungan perguruan tinggi, minimnya pengetahuan SDM perguruan tinggi dalam mengoptimalkan teknologi digital dan infrastruktur menjadi potret permasalahan mendasar dalam menjalankan operasional akademik. Dampaknya, kebutuhan mahasiswa tidak terpenuhi. Dari sisi pengelolaan, komitmen unsur manajemen perguruan tinggi juga sering kali menjadi permasalahan tersendiri. Pendanaan yang kurang terhadap infrastruktur teknologi menjadi faktor rendahnya efektivitas pelayanan teknologi dan sistem informasi di perguruan tinggi. Dengan melihat berbagai permasalahan yang ada, permasalahan sama juga terjadi pada PTKB. Masih ditemukan berbagai kendala berkaitan dengan pelayanan teknologi dan sistem informasi di PTKB. Tidak adanya sistem akademik, data akademik tidak tersentral, bandwith internet rendah, tidak adanya e-library dan Open Journal System (OJS), serta SDM teknologi informasi yang kurang menjadi permasalahan beberapa PTKB di Indonesia (Heriyanto, 2016). Kaitannya dengan pelayanan teknologi dan sistem informasi pada PTKB, kendala yang sering muncul dalam memenuhi berbagai aspek dan indikator penilaian mutu perguruan tinggi adalah tidak adanya data dan informasi berkaitan dengan tingkat kepuasan pelayanan sistem informasi pada perguruan tinggi. Beberapa poin penilaian terisi atas dasar subjektivitas tidak berdasarkan data dan kajian yang empiris dengan berbagai metode yang ilmiah.

Dengan melihat berbagai permasalahan layanan sistem informasi perguruan tinggi berserta fenomena yang mengikuti, menjadi dasar penulis untuk melakukan penelitian dengan judul "Kepuasan Mahasiswa Program Studi Pendidikan Agama Buddha terhadap Pelayanan Teknologi dan Sistem Informasi Perguruan Tinggi Keagamaan Buddha Di Tangerang". Belum dipahaminya bagaimanakah kepuasan mahasiswa Prodi PAB terhadap pelayanan teknologi dan sistem informasi PTKB di Tangerang menjadi permasalahan tersendiri dalam penelitian ini. Penelitian ini berfokus pada kepuasan mahasiswa Prodi PAB terhadap pelayanan teknologi dan sistem informasi. Pemilihan mahasiswa Prodi PAB karena mahasiwa program studi tersebut mendominasi pada PTKB dibandingkan dengan program studi lainnya (misalnya kepnyuluhan). Pada PTKB di Tangerang yaitu STABN Sriwijaya dan STAB Dharma Widya, Prodi PAB merupakan program studi dengan jumlah mahasiswa melibihi program studi lainnya. Pada STAB Dharma Widya pada Tahun Akademik 2018-2019, seluruh mahasiswa hanya ada pada satu prodi yaitu Pendidikan Agama Buddha. Hasil penelitian diharapkan memberikan deskripsi dan gambaran kepuasan mahasiswa Prodi 
Jurnal Vijjacariya, Volume 6 Nomor 2, Tahun 2019

PAB terhadap layanan teknologi dan sistem informasi yang diberikan PTKB di Tangerang.

\section{KAJIAN TEORI \\ Perguruan Tinggi Keagamaan Buddha \\ Dalam Peraturan Menteri Agama Republik Indonesia Nomor 39 Tahun} 2014 tentang Pendidikan Keagamaan Buddha, Pendidikan Keagamaan Buddha adalah pendidikan yang mempersiapkan peserta didik untuk dapat menjalankan peranan yang menuntut penguasaan pengetahuan tentang ajaran agama Buddha dan/atau menjadi ahli ilmu agama dan mengamalkan ajaran agamanya. Pendidikan keagamaan meliputi pendidikan keagamaan Islam, Kristen, Katolik, Hindu, Buddha, dan Konghucu. Perguruan Tinggi Kegamaan Buddha Negeri (PTKBN) merupakan PTKB yang didirikan dan diselenggarakan oleh Pemerintah. Perguruan Tinggi Keagamaan Buddha Swasta (PTKBS) merupakan PTKB yang didirikan dan diselenggarakan oleh masyarakat. Badan penyelenggara PTKBS adalah badan hukum nirlaba yang dapat berbentuk yayasan/perkumpulan/perserikatan/paguyuban.

\section{Pelayanan Perguruan Tinggi}

Pada institusi pendidikan khususnya perguruan tinggi, pelayanan yang diberikan berkaitan dengan adanya interaksi antara perguruan tinggi dengan mahasiswa dan masyarakat, yang secara baku tertuang dalam Tridharma Perguruan Tinggi. Kualitas pelayanan pada perguruan tinggi, merupakan perbandingan harapan mahasiswa dengan kinerja perguruan tinggi berkaitan dengan pelayanan akademik yang diberikan. Pelayanan yang dirasakan oleh mahasiswa dalam hal ini penerima jasa pendidikan pada akhirnya dapat menentukan tingkat kepuasan (customer satisfaction) mahasiswa. Parasuraman, Zeithml, Berry yang dikutip oleh Fandy Tjiptono (2012: 174), menyatakan agar kualitas pelayanan yang diharapkan dapat dicapai maka penilaian kualitas pelayanan jasa didasarkan pada "lima dimensi kualitas yaitu tangible, reliable, responsiveness, assurance dan emphaty". Lima dimensi pelayanan jasa tidak terlepas dalam Perguruan Tinggi, tangible, reliable, responsiveness, assurance dan emphaty akan dirasakan oleh mahasiswa sebagai konsumen dan pengguna jasa pendidikan (Khodayari \& Khodayari, 2011: 38-46).

Pelayanan sistem informasi dalam perguruan tinggi merupakan seluruh keterkaitan manajemen pengelolaan berkaitan dengan pemrosesan data akademik, kepegawaian, dan umum. Pelayanan sistem informasi mengarah penuh pada proses utama pembelajaran, penelitian, dan pengabdian kepada masyarakat. Pelayanan sistem informasi yang diberikan berkaitan dengan adanya interaksi antara perguruan tinggi dengan mahasiswa dan masyarakat, yang secara baku tertuang dalam Tridharma Perguruan Tinggi. Kualitas pelayanan sistem informasi pada perguruan tinggi, merupakan perbandingan harapan mahasiswa dengan kinerja perguruan tinggi berkaitan dengan pelayanan akademik yang diberikan. 
Pelayanan teknologi dan sistem informasi perguruan tinggi tidak hanya terdiri dari hardware dan software, tetapi juga meliputi cara-cara, respon, dan tanggapan tenaga kependidikan dalam memberikan layanan, yang tentunya berkontribusi besar terhadap persepsi mahasiswa terhadap layanan yang diberikan. Pelayanan teknologi dan sistem informasi perguruan tinggi juga merupakan unsur komunikasi dengan dukungan teknologi komputer untuk menghasilkan informasi yang dibutuhkan dan digunakan mahasiswa dalam menempuh pendidikan di perguruan tinggi.

\section{Kepuasan Mahasiswa}

Kepuasan adalah tingkat perasaan seseorang setelah membandingkan kinerja atau hasil yang dirasakannya dengan harapan yang dimiliki. Kepuasan mahasiswa dipengaruhi oleh berbagai faktor, seperti apresiasinya terhadap ilmu atau keterampilan yang diperoleh, pelayanan akademik yang diberikan perguruan tinggi, terpenuhinya kebutuhan akademik dengan dukungan sarana dan prasarana, berbagai peraturan dan kebijakan dalam penyelenggaraan proses akademik, serta harapan-harapan atau ekspektasinya terhadap perguruan tinggi yang telah memberikan jasa pelayanan (services) kepadanya sebagai pelanggan (customer). Tingkat kepuasan mahasiswa sebagai pelanggan dari jasa pendidikan yang dilakukan perguruan tinggi dapat diukur dengan lima dimensi, yaitu tangible, realibility, responsiveness, assurance, dan empathy.

\section{METODE PENELITIAN}

Jenis penelitian ini adalah penelitian deskriptif, dengan pendekatan kuantitatif. Subjek penelitian adalah mahasiswa Prodi PAB pada PTKB di Tangerang yang aktif pada tahun akademik 2018-2019. Objek penelitian adalah kepuasan mahasiswa terhadap pelayanan teknologi dan sistem informasi. Penelitian ini merupakan penelitian populasi. Pengumpulan data dengan teknik nontes menggunakan kuesioner. Lokasi penelitian yaitu STABN Sriwijaya dan STAB Dharma Widya. Kuesioner menggunakan empat klasifikasi berdasarkan skala Likert. Kepuasan mahasiswa terhadap pelayanan teknologi dan sistem informasi diukur melalui bentuk dimensi tangible, reliability, responsiveness, assurance, dan emphaty. Teknik analisis data dengan teknik statistik deskriptif menggunakan nilai rata-rata (mean) dan standar

deviasi. Interpretasi persentase kepuasan mahasiswa dilakukan dengan kriteria interpretasi skor berdasarkan interval.

\section{HASIL DAN PEMBAHASAN \\ Kepuasan Mahasiswa Prodi PAB terhadap Pelayanan Teknologi dan Sistem Informasi PTKB di Tangerang}

Kepuasan mahasiswa Prodi PAB terhadap pelayanan teknologi dan sistem informasi PTKB di Tangerang didapatkan melalui membagi skor total jawaban responden dengan skor total maksimal jawaban responden, 
kemudian dikalikan dengan $100 \%$. Skor total jawaban responden mewakili persepsi terhadap apa yang dirasakan mahasiswa berkaitan dengan pelayanan teknologi dan sistem informasi yang mereka terima. Sedangkan skor total maksimal menjadi nilai pembanding yang mewakili harapan mahasiswa terhadap maksimalnya pelayanan teknologi dan sistem informasi yang seharusnya mereka terima. Persentase digunakan untuk mengetahui gambaran secara umum mengenai kepuasan mahasiswa terhadap pelayanan teknologi dan sistem informasi. Hasil pengolahan data penelitian menghasilkan kepuasan mahasiswa Prodi PAB terhadap pelayanan teknologi dan sistem informasi PTKB di Tangerang adalah sebesar 77,28\%. Interpretasi yang didapat dengan mencari interval skor persen berdasarkan skala Likert menyatakan 77,28\% termasuk dalam kategori sangat puas.

Kategorisasi Tingkat Kepuasan Mahasiswa Prodi PAB terhadap Pelayanan Teknologi dan Sistem Informasi PTKB di Tangerang

Kategorisasi dilakukan untuk menampilkan kecenderungan dua faktor utama kualitas pelayanan. Faktor utama kualitas pelayanan yaitu harapan mahasiswa dan persepsi atas kenyataan yang mereka rasakan. Kategorisasi menggunakan mean ideal dan standar deviasi ideal, dengan demikian makna data dan kecenderungan tanggapan kepuasan mahasiswa dapat terlihat untuk setiap responden. Skala kepuasan mahasiwa diklasifikasikan menjadi lima kategori, yaitu: sangat puas, puas, cukup, tidak puas, dan sangat tidak puas.

Tabel 1. Kategorisasi Kepuasan Mahasiswa Prodi PAB

\begin{tabular}{|c|l|c|c|}
\hline No. & \multicolumn{1}{|c|}{ Kategori } & Rentang & Jumlah Mahasiswa \\
\hline 1. & Sangat Puas & $\geq 249,20$ & 7 \\
\hline 2. & Puas & 223,21 s.d. 249,20 & 13 \\
\hline 3. & Cukup & 197,23 s.d. 223,21 & 42 \\
\hline 4. & Tidak Puas & 171,24 s.d. 197,23 & 21 \\
\hline 5. & Sangat Tidak Puas & $<171.24$ & 3 \\
\hline
\end{tabular}

Tabel 1 di atas menampilkan kategorisasi tingkat kepuasan mahasiswa Prodi PAB terhadap pelayanan teknologi dan sistem informasi PTKB di Tangerang. Data menggambarkan 7 mahasiswa dalam kategori sangat puas, 13 mahasiswa dalam kategori puas, 42 mahasiswa dalam kategori cukup, 21 mahasiswa dalam kategori tidak puas, dan 3 mahasiswa dalam kategori sangat tidak puas.

Untuk melihat tingkat kepuasan mahasiswa terhadap pelayanan teknologi dan sistem informasi PTKB di Tangerang dalam bentuk tinggi, sedang, dan rendah, maka dilakukan kategorisasi dengan menggunakan mean dan standar deviasi data penelitian. Pemberian ranking dilakukan dengan melihat skor total jawaban responden penelitian. 


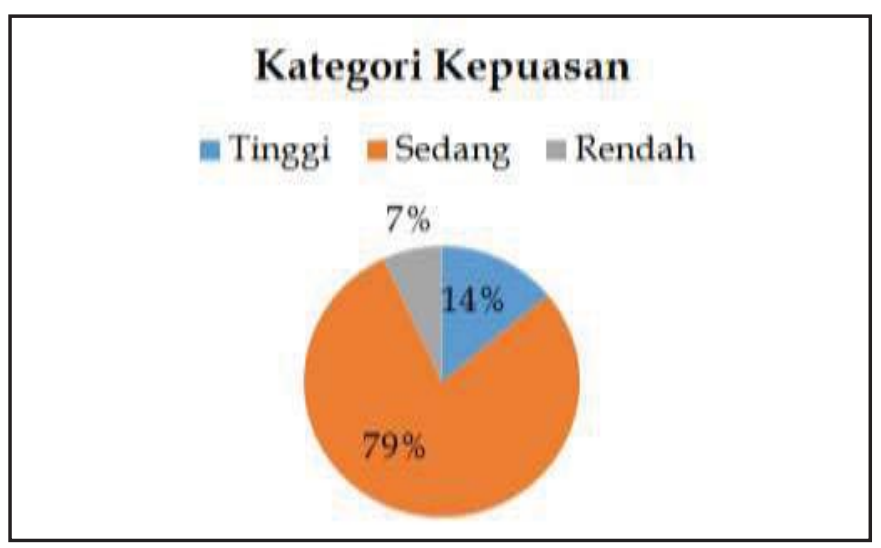

Gambar 1. Kategori Tingkat Kepuasan Mahasiswa setiap Responden

Gambar 1 menampilkan tingkat kepuasan mahasiswa Prodi PAB terhadap pelayanan teknologi dan sistem informasi PTKB di Tangerang dalam kategori tinggi, sedang, dan rendah. Tingkat kepuasan mahasiswa terhadap pelayanan teknologi dan sistem informasi PTKB di Tangerang sebesar 14,00\% kategori tinggi, 79,00\% dalam kategori sedang, dan 7,00\% kategori rendah.

Tingkat Kepuasan Mahasiswa Prodi PAB terhadap Pelayanan Teknologi dan Sistem Informasi PTKB di Tangerang untuk Setiap Dimensi

Tingkat kepuasan mahasiswa Prodi PAB terhadap pelayanan teknologi dan sistem informasi PTKB di Tangerang dapat diidentifikasi untuk setiap dimensi kepuasan. Dimensi kepuasan mahasiswa terhadap pelayanan teknologi dan sistem informasi meliputi tangible, reliability, responsiveness, assurance, dan emphaty.

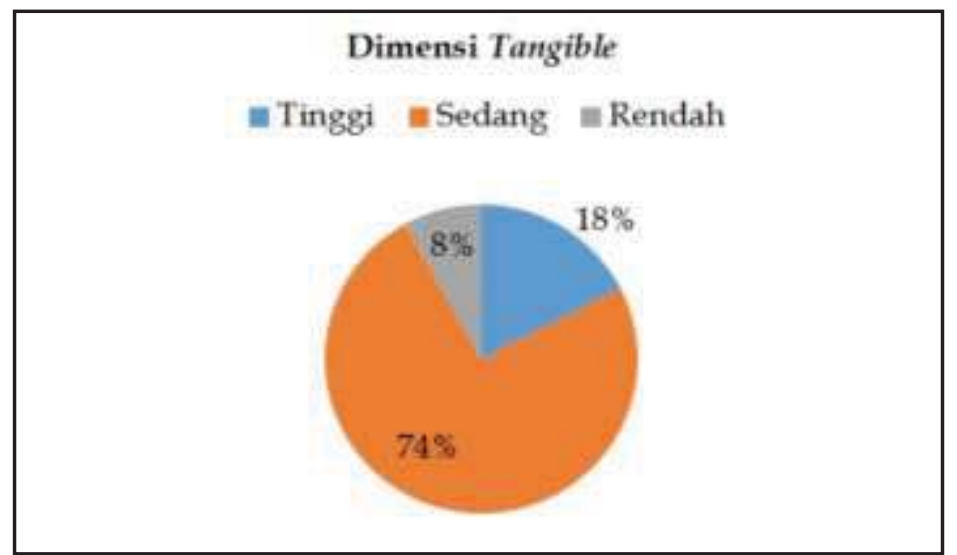

\section{Gambar 2. Tingkat Kepuasan Mahasiswa Dimensi Tangible}

Tingkat kepuasan mahasiswa terhadap pelayanan teknologi dan sistem informasi PTKB di Tangerang untuk dimensi tangible sebesar 79,51\%, termasuk dalam kategori sangat puas. Kategori tingkat kepuasan untuk setiap responden dalam menjawab butir angket penelitian dimensi tangibel berada pada $18,00 \%$ kategori tinggi, $74,00 \%$ kategori sedang, dan 8,00\% kategori 
rendah. Tangible mengambarkan kepuasan mahasiswa terhadap fasilitas fisik, perlengkapan, pegawai, dan sarana komunikasi. Kebutuhan pengguna jasa yang berfokus pada fasilitas fisik seperti gedung dan ruangan, tersedia tempat parkir, kebersihan, kerapian dan kenyamanan ruangan, kelengkapan peralatan, sarana komunikasi, serta penampilan tenaga kependidikan.

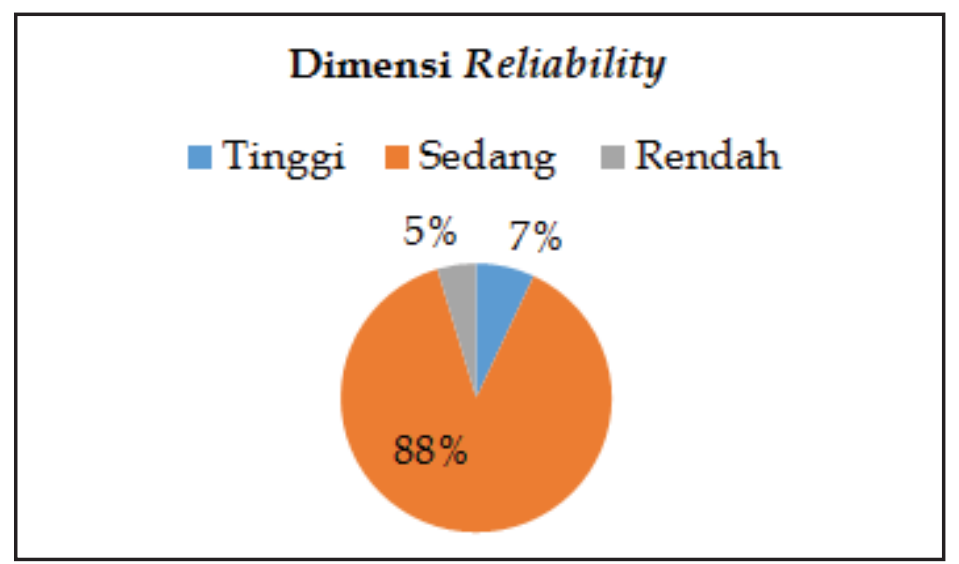

\section{Gambar 3. Tingkat Kepuasan Mahasiswa Dimensi Reliability}

Tingkat kepuasan mahasiswa Prodi PAB terhadap pelayanan teknologi dan sistem informasi PTKB di Tangerang untuk dimensi reliability sebesar $76,82 \%$. Sedangkan kategori tingkat kepuasan untuk setiap responden dalam menjawab butir angket penelitian berada pada kategori tinggi sebesar 7,00\%, sedang 88,00\%, dan 5,00\% kategori rendah. Reliability menggambarkan kepuasan mahasiswa terhadap pelayanan yang dijanjikan dengan tepat waktu, akurat, dan memuaskan. Reliability juga meliputi memberikan pelayanan sesuai dengan apa yang dijanjikan secara akurat dan terpercaya. Dengan reliability kinerja harus sesuai dengan harapan mahasiswa yang berarti ketepatan waktu, pelayanan yang sama untuk semua mahasiswa tanpa kesalahan, sikap yang simpatik, dan dengan akurasi yang tinggi. Pemenuhan janji dalam pelayanan akan mencerminkan kredibilitas perguruan tinggi yang tercermin melalui jurusan dan program studi.

Tingkat kepuasan mahasiswa Prodi PAB terhadap pelayanan teknologi dan sistem informasi PTKB di Tangerang untuk dimensi responsiveness sebesar $77,17 \%$. Sedangkan kategori tingkatan kepuasan untuk setiap responden dalam menjawab butir angket penelitian berada pada kategori tinggi sebesar $15,00 \%$, sedang $74,00 \%$, dan kategori rendah 11,00\%. Dimensi responsiveness merupakan kemampuan para tenaga kependidikan untuk membantu mahasiswa dan memberikan pelayanan dengan tanggap. Respons atau kesiapan tenaga kependidikan dalam membantu mahasiswa dan memberikan pelayanan yang cepat, yang meliputi kesiapan melayani, kecepatan dalam menangani transaksi serta penanganan keluhan mahasiswa. 


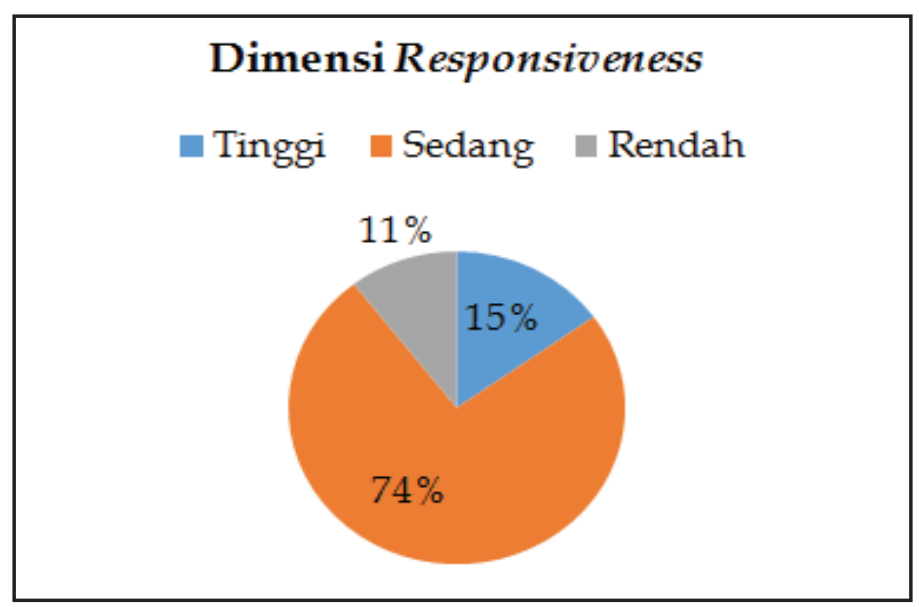

Gambar 4. Tingkat Kepuasan Mahasiswa Dimensi Responsiveness

Gambar 5. menampikan tingkat kepuasan mahasiswa terhadap pelayanan teknologi dan sistem informasi PTKB di Tangerang untuk dimensi assurance. Dimensi assurance mencakup kemampuan, kesopanan, dan sifat dapat dipercaya yang dimiliki para tenaga kependidikan dan dosen, bebas dari bahaya, risiko atau keraguan. Assurance juga merupakan kemampuan dalam menanamkan kepercayaan mahasiswa terhadap perguruan tinggi.

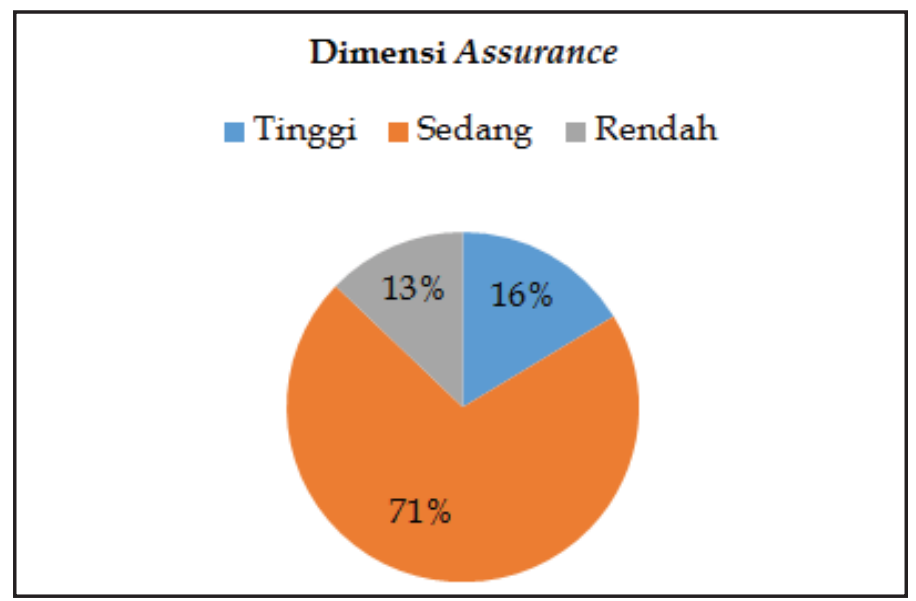

Gambar 5. Tingkat Kepuasan Mahasiswa Dimensi Assurance

Tingkat kepuasan mahasiswa terhadap pelayanan teknologi dan sistem informasi PTKB di Tangerang untuk dimensi assurance sebesar 77,42\%, dengan $16,00 \%$ kategori tinggi, 71,00\% kategori sedang, dan 13,00\% kategori sedang. 


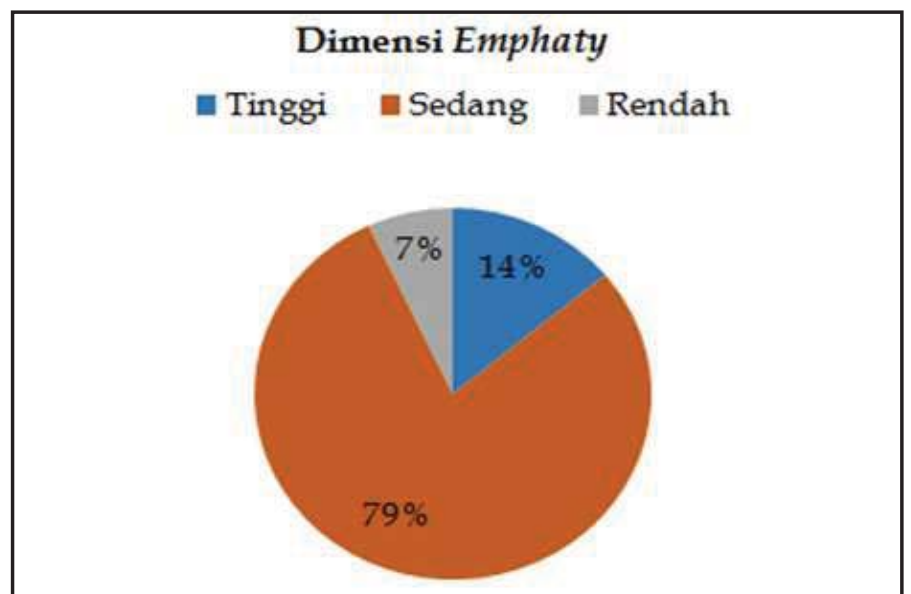

\section{Gambar 6. Tingkat Kepuasan Mahasiswa Dimensi Emphaty}

Tingkat kepuasan mahasiswa Prodi PAB terhadap pelayanan teknologi dan sistem informasi PTKB di Tangerang untuk dimensi emphaty sebesar $75,56 \%$. Sedangkan kategori tingkatan kepuasan untuk setiap responden dalam menjawab butir angket penelitian berada pada kategori tinggi sebesar 14,00\%, sedang 79,00\% , dan kategori rendah 7,00\%. Gambar 6. menampilkan tingkat kepuasan mahasiswa Prodi PAB terhadap pelayanan teknologi dan sistem informasi PTKB di Tangerang untuk dimensi emphaty. Dimensi emphaty mencakup kemudahan dalam melakukan komunikasi yang baik dan memahami kebutuhan para mahasiswa. Emphaty merupakan perhatian dengan memberikan sikap yang tulus dan berifat individual atau pribadi yang diberikan kepada mahasiswa seperti kemudahan untuk menghubungi jurusan dan program studi, kemampuan dosen dan tenaga kependidikan untuk berkomunikasi dengan mahasiswa.

\section{PENUTUP}

Dari hasil analisis data dan pembahasan, dapat diambil kesimpulan sebagai berikut:

1. Kepuasan mahasiswa Prodi PAB terhadap pelayanan teknologi dan sistem informasi PTKB di Tangerang sebesar 77,28\%. Interpretasi yang didapat dengan mencari interval skor persen berdasarkan skala Likert menyatakan 77,28\% termasuk dalam kategori sangat puas.

2. Tingkat kepuasan mahasiswa Prodi PAB terhadap pelayanan teknologi dan sistem informasi PTKB di Tangerang sebesar 14,00\% dalam kategori tinggi, $79,00 \%$ kategori sedang, dan 7,00\% dalam kategori rendah.

3. Tingkat kepuasan mahasiswa Prodi PAB terhadap pelayanan teknologi dan sistem informasi PTKB di Tangerang untuk dimensi tangible sebesar 79,51\%, kategori sangat puas. Kategori tingkat kepuasan untuk setiap responden dalam menjawab item angket penelitian dimensi tangibel berada pada $18,00 \%$ kategori tinggi, 74,00\% kategori sedang, dan 8,00\% kategori rendah. 
4. Tingkat kepuasan mahasiswa Prodi PAB terhadap pelayanan teknologi dan sistem informasi PTKB di Tangerang untuk dimensi reliability sebesar $76,82 \%$. Sedangkan kategori tingkat kepuasan untuk setiap responden dalam menjawab butir angket penelitian berada pada kategori tinggi sebesar 7,00\%, sedang 88,00\%, dan 5,00\% kategori rendah.

5. Tingkat kepuasan mahasiswa Prodi PAB terhadap pelayanan teknologi dan sistem informasi PTKB di Tangerang untuk dimensi responsiveness sebesar $77,17 \%$. Sedangkan kategori tingkatan kepuasan untuk setiap responden dalam menjawab butir angket penelitian berada pada kategori tinggi sebesar $15,00 \%$, sedang 74,00\%, dan kategori rendah $11,00 \%$.

6. Tingkat kepuasan mahasiswa Prodi PAB terhadap pelayanan teknologi dan sistem informasi PTKB di Tangerang untuk dimensi assurance 77,42\%, dengan 16,00\% kategori tinggi, 71,00\% kategori sedang, dan 13,00\% kategori rendah.

7. Tingkat kepuasan mahasiswa Prodi PAB terhadap pelayanan teknologi dan sistem informasi PTKB di Tangerang untuk dimensi emphaty sebesar $75,56 \%$. Kategori kepuasan untuk setiap responden dalam menjawab butir angket penelitian berada pada kategori tinggi sebesar $14,00 \%$, sedang $79,00 \%$, dan kategori rendah 7,00\%.

\section{DAFTAR PUSTAKA}

Abdullah, Sukirno, Annisa, dkk. (2013). Analisis Kualitas Pelayanan terhadap Kepuasan Mahasiswa pada Fakultas Ekonomi Universitas Negeri Yogyakarta. Jurnal Nominal Fakultas Ekonomi Universitas Negeri Yogyakarta, $I I(I)$.

Ekowiswoyo, Rasdi. (2015). Mutu Layanan dan Kepuasan Mahasiswa: Studi

Kasus di Universitas Negeri Semarang. Jurusan Pendidikan Luar Sekolah, Fakultas Ilmu Pendidikan, Universitas Negeri Semarang. Jurnal Penelitian Pendidikan, 32(1).

Ganesh, R. dan Haslinda, A. (2014). Evolution and Conceptual Development of Service Quality in Service Marketing and Customer Satisfaction. International Review of Management and Business Researc, 3(2).

Heriyanto. (2016). PEST Analysis Sebagai Strategi Peningkatan Pelayanan Perguruan Tinggi Keagamaan Buddha. Jurusan Dharmacarya, STABN Sriwijaya.

Heriyanto. (2017). Pengaruh Pelayanan dan Fasilitas terhadap Kepuasan Mahasiswa Sekolah Tinggi Agama Buddha Negeri Sriwijaya Tangerang Banten. Jurnal Vijjacariya, Jurusan Dharmacarya, STABN Sriwijaya.

Heriyanto. (2018). Strategi Digital Perguruan Tinggi Keagamaan Buddha di Indonesia. Jurusan Dharmacarya, STABN Sriwijaya.

Indrajit \& Djokopranoto. Manajemen Perguruan Tinggi Moderen. n.p. n.d. Print.

Kementerian Komunikasi dan Informatika Republik Indonesia. (2017). Survei Penggunaan TIK Tahun 2017. Pusat Penelitian dan Pengembangan 
Jurnal Vijjacariya, Volume 6 Nomor 2, Tahun 2019

Aplikasi Informatika dan Komunikasi Publik dan Badan Penelitian dan Pengembangan Sumber Daya Manusia.

Khodayari, F., \& Khodayari, B. (2011). Service Quality in Higher Education. Interdisciplinary Journal of Research in business, 1(3), h. 8-46.

Kotler, Keller. (2009). Manajemen Pemasaran. Yogyakarta: Graha Ilmu.

Kotler, Keller. (2012). Marketing Management 14th. New York: Prentice Hall.

Larasati, Citra. (2018). Kesenjangan Digital di Indonesia Masih Tinggi. https://www.medcom.id/pendidikan/news-pendidikan/0Kvq9nok-

kesenjangan-digital-di-indonesia-masih-tinggi (diakses 12 Februari 2019).

Laudon., Kenneth C, Laudon., Jane P. (2012). Management Information Systems: Managing The Digital Firm, $12^{\text {th }}$ Edition. New Jersey: Prentice Hall Inc.

Peraturan Menteri Agama Republik Indonesia Nomor 39 Tahun 2014, Tentang Pendidikan Keagamaan Buddha.

Parasuraman, Zeithaml, Berry L. (1985). Problems and Strategies in Services Marketing. Jurnal of Marketing, Vol. 49. (Spring).

Rahmawati, Diana. (2013). Analisis Faktor-Faktor yang mepengaruhi Kepuasan Mahasiswa. Jurnal Economia, 9(1).

Romney, Marshal R. \& Paul John Steinbart. (2015). Sistem Informasi Akuntansi. Jakarta: Salemba Empat.

Rusman. (2011). Model-model Pembelajaran, Mengembangkan Profesionalisme Guru. Jakarta: Raja Grafindo Persada.

Sinambela, P.L. (2010). Reformasi Pelayanan Publik Teori, Kebijakan, dan Implementasi. Jakarta: PT. Bumi Aksara.

Sutabri, Tata. (2012). Konsep Sistem Informasi. Yogyakarta: Penerbit ANDI.

Tjiptono, Fandy. (2012). Service Management Mewujudkan Layanan Prima (edisi II). Yogyakarta: Andi Offset.

Tjiptono, Fandy. (2012). Service Management: Mewujudkan Layanan Prima Edisi II. Yogyakarta: Andi.

Turban, E., Rainner R.K., \& Potter, Richard E. (2010). Introduction to Information Technology. 3rd Edition. USA: Wiley.

Ward, John \& Joe Peppard. (2002). Strategic Planning For Information System, $2^{\text {th }}$ ed. John England: Wiley \& Sons.

Ward, John. \& Joe Peppard. (2002). Strategic Planning for Information System 3nd ed. England: John Wiley \& Sons.

Wijaya, D. (2012). Pemasaran Jasa Pendidikan. Jakarta: Salemba Empat. 